\title{
Expanding the Utilization of Robotic Procedures in Urologic Surgery
}

\author{
Tareq Aro, M.D. ${ }^{1,2}$, Michael Mullerad, M.D. ${ }^{1,2}$, and Gilad E. Amiel, M.D.1,2 \\ ${ }^{\prime}$ Urology Department, Rambam Health Care Campus, Haifa, Israel; and ${ }^{2}$ Rappaport Faculty of Medicine, \\ Technion-Israel Institute of Technology, Haifa, Israel
}

\begin{abstract}
Although the word "robot" was coined in 1921, only close to 70 years later were robotic devices developed to assist during surgery. Urology has always been at the forefront of endoscopic, minimally invasive, and robotic developments in medicine. Robotic prostatectomy signaled the emerging role of robotic surgery in urology, but since then it has been applied to every urologic laparoscopic procedure.
\end{abstract}

KEY WORDS: Laparoscopy, robotic surgery, urology

\section{INTRODUCTION}

Karel Čapek first coined the word "robot" in his play R.U.R. (Rossum's Universal Robots), in 1921. ${ }^{1}$ The term was derived from the Czech word "robota," meaning "forced work." Čapek's play presented a world where humans were assisted by robots to fulfill everyday tasks; however, the robots eventually turned on their masters and sought world domination. ${ }^{2}$

"A computer-controlled manipulator with artificial sensing that can be reprogrammed to move and position tools to carry out a range of surgical tasks" was the definition given to a surgical robot. ${ }^{3}$ Many authors did not like this definition and suggested "computer-assisted surgery" as an alternative. 4

Invention has always been driven by necessity, and so was the development of medical robotics. EndoAssist, probably the first surgical robotic device, was introduced in 1990 and was a freestanding laparoscopic camera manipulator, con-

\footnotetext{
Abbreviations: AUA, American Urology Association; IVC, inferior vena cava; RPLND, retroperitoneal lymph node dissection; TESE, testicular sperm extraction

Citation: Aro T, Mullerad M, Amiel GE. Expanding the Utilization of Robotic Procedures in Urologic Surgery. Rambam Maimonides Med J 2017;8 (4):e0044. Review. doi:10.5041/RMMJ.10320

Copyright: (c) 2017 Aro et al. This is an open-access article. All its content, except where otherwise noted, is distributed under the terms of the Creative Commons Attribution License (http://creativecommons.org/licenses/by/3.0), which permits unrestricted use, distribution, and reproduction in any medium, provided the original work is properly cited.
}

Conflict of interest: No potential conflict of interest relevant to this article was reported.

* To whom correspondence should be addressed. E-mail: t_arow@rambam.health.gov.il 
trolled by infrared signals from a headset worn by the surgeon. ${ }^{2}$ The first robot-assisted human hip replacement was performed in California using a Robodoc in 1992.5

Automated Endoscopic System for Optimal Positioning (AESOP) was manufactured by Computer Motion and used voice (or pedal) control. ${ }^{6}$ AESOPTM 1000 in 1993 was the first commercially used robotic assistant, used to hold the endoscopic camera in laparoscopic surgery, and was shown to be steadier and more effective than human assistance.7

The ZEUS ${ }^{\text {TM }}$ Robotic Surgical System used in 1998 consisted of three robotic arms attached to the side of the operating table and controlled with a hand-held joystick. This was the first system allowing a surgeon to control laparoscopic instruments. The ZEUSTM Robotic Surgical System was used for the first transatlantic surgery in 2001, when a surgeon in New York performed cholecystectomy on a patient in France. ${ }^{8}$

The da Vinci Surgical System developed by Intuitive Surgical made a giant leap in the use of robotics in surgery by bringing the most advanced "masterslave" system developed. The basic principle involves control of three or four robotic arms by a surgeon sitting at a console. The system has three components: a surgeon console, a patient-side cart, and an image-processing stack. ${ }^{2}$

In the year 2000 there were reports of about 1,500 robotic surgeries worldwide, and this number increased to more than 20,000 by the year 2004.5 While the initial reports of robotic surgery were in the field of cardiac surgery, the vast majority of these procedures are performed in urology nowadays. Most notable is radical prostatectomy, where the procedure was performed robot-assisted in about $10 \%$ of cases in the United States in $2006^{2}$ and almost entirely performed robotically in the United States nowadays. In the last decade, urologic surgeons have constantly expanded the use of the robot for increasingly complex procedures. Our goal was to survey those cases and describe the expansion of robotic surgery in urology.

\section{METHODS}

An online PubMed search for key words involving robotic surgery, urology, or the name of specific procedures was performed. Also, a targeted search for robotic surgery and technologies publications in the last two American Urology Association meetings was undertaken.

\section{HISTORIC MILESTONES IN ROBOTIC UROLOGIC SURGERY}

Urology has always been at the forefront of endoscopic, minimally invasive, and robotic developments in medicine. Robotic prostatectomy signaled the emerging role of robot surgery in urology, but since then it has been applied to every urologic laparoscopic procedure. The only factor that hindered progress of robotics at its beginning was the initial high costs of the device itself.

The advantage of robotic over conventional laparoscopic procedures is obviously more pronounced in procedures requiring complex reconstructive techniques, and so the simpler procedures, even though they can be performed robotically, are likely to be performed using other techniques, including free hand laparoscopy.

\section{Adrenalectomy}

The adrenals are situated in a deep anatomic position, which is ideal for a laparoscopic approach, and so the robotic approach presents obvious advantages. Horgan et al. ${ }^{9}$ were the first to perform robotic laparoscopic adrenalectomy in humans in 2001. By 2003 there were several reports of the advantages of using the robotic approach. ${ }^{10,11}$ However, most adrenalectomies being performed today are still through the laparoscopic approach.

\section{Renal Surgery}

\section{Simple and Radical Nephrectomy}

Laparoscopy remains the most widely used method for both simple and radical nephrectomy to date. The first laparoscopic nephrectomy was described by Ratner et al. in $1995 \cdot{ }^{12}$ The ease of the operation, and the lack of complex maneuvers, makes the use of the robot unnecessary. In 2005 Klingler et al. ${ }^{13}$ described the first robotic nephrectomy.

\section{Partial Nephrectomy}

As our understanding of renal cell carcinoma grew larger, the main surgical treatment of localized lesions today is partial nephrectomy compared to the previous gold standard-radical nephrectomy.

There were clear benefits for the laparoscopic approach to the deeply positioned kidney that is 
surrounded by several vital structures from every direction.

The main problem with the laparoscopic approach for partial nephrectomy was the need for difficult maneuvers and suturing which was responsible for a challenging operation with a steep learning curve.

The first robotic partial nephrectomy was published in 2005. ${ }^{14}$ The introduction of the robotic system made this surgery less challenging to perform. By $2013,64.1 \%$ of partial nephrectomies in the USA were performed robotically. ${ }^{15}$

\section{Vena Cava Thrombectomy}

After gaining enough experience in robotic renal surgery, surgeons felt comfortable performing more complicated procedures, including the evacuation of tumors extending from the kidney into the vena cava. The first robotic nephrectomy with an inferior vena cava (IVC) tumor extension was in 2008 and the first series published in 2011. ${ }^{16}$ Nonetheless, the vast majority of level II and above vena cava thrombectomy cases are still performed in an open fashion.

\section{Nephroureterectomy}

The standard treatment of upper-tract transitional cell carcinoma is nephroureterectomy with bladder cuff excision. Several reports demonstrated similar results between the open and laparoscopic technique. The learning curve for performing the operation laparoscopically was too difficult to make it a widespread technique, even though it was shown to be feasible. ${ }^{17,18}$ Robotic nephroureterectomy was first reported in 2006 by Rose et al. ${ }^{19}$ Nonetheless, the majority of cases are probably still performed via a laparoscopic approach.

\section{Live-donor Nephrectomy}

The first series of robotic live-donor nephrectomies was reported in 2001 by the University of Illinois at Chicago.9,20 However, just like radical nephrectomy, most current reported series are performed via the laparoscopic approach.

\section{Kidney Transplantation}

The first attempted robotic kidney transplantation was performed in France in 2001 but was not performed fully using the robot. ${ }^{20}$ Since then there have been many reports and publications trying to perfect the technique, and the first fully robotic transabdominal transplantation was reported in 2010. ${ }^{21}$

The disadvantages of the robot included the need for methods to cool the kidney and pelvis to prevent longer warm ischemia time and reports of longer times to creatinine clearance improvement, which is thought to be attributed to the positive pressure during pneumoperitoneum.

Still, there is value in the robotic approach especially in morbidly obese patients who were otherwise denied kidney transplant due to increased risk of surgical site infection. ${ }^{22}$

\section{Pyeloplasty}

Laparoscopic dismembered pyeloplasty was first performed in 1993, and further reports showed similar success rates to open pyeloplasty. The laparoscopic approach remains a challenging procedure even in larger series. ${ }^{23}$ The increased dexterity and precision make robotic pyeloplasty an attractive alternative option. The robotic approach is used both in adults and in the pediatric population. ${ }^{24-26}$

\section{Ureteral Surgery}

All operations involving the ureter (whether distal or partial ureterectomy; reimplantation of the ureter; or primary ureter anastomosis) require advanced techniques that are extremely difficult to perform laparoscopically. The robotic system allows the surgeon to expand its ability to perform dissections and sutures similar to open surgery without the necessity for a large incision. Continuous sutures present an easier technique than interrupted in the laparoscopic and robotic settings. ${ }^{27-29}$ Musch et al. published in 2013 a series of a single-institution experiences with distal ureteral reconstructive surgery with good results. ${ }^{30}$

\section{Bladder Surgery}

\section{Cystectomy}

The first robotic radical cystectomy was reported in 2003. ${ }^{31}$ The operation included performing a complete intra-abdominal formation of an orthotopic ileal neobladder.

By now many studies have debated the benefits of the robotic approach compared to open cystectomy. These demonstrated equivalent results to the open approach in terms of pathological outcomes and lymph node dissection. The robotic approach causes less blood loss with longer operative times..$^{32-34}$

A randomized controlled trial published in 2015 showed similar 30-day and 90-day complication rates for the two approaches, with 90-day complication rates of $62 \%$ in the robotic group and $66 \%$ in the open approach. ${ }^{2}$ 
A review of 19 studies including 1,779 patients in 2015 demonstrated better outcomes with the robotic approach, demonstrating a greater lymph node yield, fewer perioperative complications, less blood loss and need of transfusions, and shorter hospital stays. 35

Another review article comparing the two operations demonstrated the same results of better perioperative outcomes in the robotic group, with noninferiority results in terms of oncological outcomes..$^{6}$

By 2010 the number of robotic radical cystectomies in the USA had risen to $12.8 \%, 37$ and by 2015 it was published that most academic centers in the USA have adopted the robotic approach for the operation. 38

We are currently anticipating the results of the multi-institutional RAZOR (randomized open versus robotic cystectomy) trial that started in 2014 and which may become a landmark in the future of radical cystectomy. 39 We reported the first series of robotic cystectomy in Israel in $2015^{40}$ and a series of post-radiation salvage cystectomies in $2017.4^{11}$

\section{Partial Cystectomy}

Partial cystectomy is a less common operation than the gold standard radical cystectomy for bladder cancer, but there are a few indications for performing partial cystectomy including for non-malignant causes. By the year 2010 the first reports of performing the operation robotically emerged. ${ }^{42}$ However, although feasible, it is not considered standard of care, and therefore no reports of large series have been published.

\section{Bladder Augmentation}

Bladder augmentation is performed mainly in patients with neurogenic bladder. The first complete laparoscopic ileal cystoplasty was reported in 2002 in an adult.43 By 2004 the first appendicovesicostomy (Mitrofanoff procedure) in a child was reported,44 and in 2008 the first robotic operation was published. 45

\section{Urinary Diversion}

In 1950, Bricker described the first ileal conduit. ${ }^{46}$ The Wallace method of uretero-ileal anastomosis was described in 1966.47 Many methods were described over the years for continent versus incontinent urinary diversions, and ileal conduit remains the most commonly used urinary diversion technique. 48
To date, most of urinary diversions are still performed extracorporeally; still, there is a rising number of surgeons performing both types of diversions intracorporeally with advances in technique still being published.

\section{Prostate Surgery}

\section{Simple Prostatectomy}

Mariano et al. in 2002 described the first laparoscopic simple prostatectomy for benign prostate enlargement and later on reported their 6-year experience.49,50 Due to its technical difficulty, the operation did not gain a lot of popularity.

In 2008, Sotelo et al..$^{1}$ described the first robotic simple prostatectomy which became more popular than the laparoscopic approach.

\section{Radical Prostatectomy}

The hallmark of robotic surgery is still robotic radical prostatectomy. In 1991, Clayman and colleagues performed the first laparoscopic radical prostatectomy, which was published in their series of nine patients in $1997 . .^{2}$ In 2001, the Henry Ford Hospital described the first robotic radical prostatectomy.53 Since then the robotic approach has become the procedure of choice in the US and in many centers worldwide.

In July, 2016 the first randomized controlled trial comparing the open radical prostatectomy to robotic radical prostatectomy was published in The Lancet, showing superiority of the robotic approach in intraoperative complications, blood loss, hospital stay, and postoperative complications. 54

\section{Nerve Grafting}

Despite advances in the technique of robotic radical prostatectomy, and despite the practice of nerve sparing, adequate cancer control may require sacrificing the neurovascular bundle during surgery. A number of studies have demonstrated the feasibility of immediate nerve reconstruction after prostatectomy. However, clinical outcomes have been mixed.55 One well-designed randomized controlled trial demonstrated no benefit of unilateral nerve grafting after prostatectomy. .56

Even though results are still debatable and the need for the procedure remains questionable, in 2003 the first reports of robotic sural nerve grafting technique was published. ${ }^{57}$ Since then, however, sural nerve grafting has been abandoned completely. 
Retroperitoneal Lymph Node Dissection Despite retroperitoneal lymph node dissection (RPLND) being one of the most challenging operations in urology to perform laparoscopically, some high-volume centers with dedicated surgeons perform RPLND, mainly primary rather than post chemo. ${ }^{8}$ In 2011 the first publication of robotic RPLND appeared.59 Recently, robotic surgeons started publishing their initial series with excellent results. ${ }^{60}$

\section{Microsurgery}

In recent years there has been an expanding use of the robotic system for microsurgical procedures.

\section{Vasectomy Reversal}

The first evolution in infertility treatment came in 2004 with the first da Vinci microsurgical vasectomy reversal.61,62 Parekattil et al. reported similar outcomes comparing the robotic to the pure microsurgical technique. ${ }^{63}$ However, those results were in the beginning of the robotic era and without a skilled microsurgery assistant. ${ }^{62}$ Some recent publications show the benefit of the robotic approach in difficult anatomical situations, as in Trost et al. describing a bilateral intracorporeal vasovasostomy in a case of iatrogenic bilateral obstruction following hernia repair. ${ }^{64}$

\section{Varicocelectomy}

The first experience with subinguinal roboticassisted varicocelectomy came in 2008,65 and Mechlin and McCullough published in 2013 good outcomes of the procedure along with an observation that this method provided a better controlled environment for training of residents and fellows. ${ }^{66}$

\section{Testicular Sperm Extraction}

Microsurgical testicular sperm extraction (TESE) has the highest sperm retrieval rate among the various retrieval methods for non-obstructive azoospermia. ${ }^{67}$ The procedure utilizes simultaneous imaging of the tissue by an embryologist which is further enhanced by the combination of the robotic system and new sperm imaging detection techniques. ${ }^{62}$

\section{Targeted Denervation of the Spermatic Cord}

The procedure is aimed at treating patients with chronic groin or scrotal pain. A 2014 publication demonstrated complete pain resolution in $70.5 \%$ of patients and significant improvement in $84.8 \%$ of patients. 68
In a recent conference (RAMSES, Maastricht, March 2017) there were several video sessions on advancing urologic robotic microsurgical techniques, including microsurgical denervation of the spermatic cord, varicocelectomy, and vasectomy reversal procedures (see: ramsesrobotics.com).

\section{RECENT DESCRIPTION OF NOVEL TECHNIQUES}

After almost 20 years of advancement in urologic robotic surgery, we continue to try and bring new technologies, perfect the different techniques, and discover various new indications for the use of the robotic laparoscopic systems in urologic practice.

In the last two American Urology Association (AUA) conferences held in San Diego in May, 2016 and in Boston in May, 2017, there were 282 and 365 publications on robotic surgery, respectively (647 in total), 397 of them (61\%) related to oncologic surgeries. Table 1 stratifies all AUA 2016 and 2017 publications. It is also worth mentioning that nine presentations were on RPLND, six presentations on robotic sacrocolpopexy, and two presentations on robotic vaginoplasty.

Table 1. Stratification of all AUA 2016 and 2017 Publications.

\begin{tabular}{l|c|}
\hline Topic & Publications \\
\hline Prostate & 191 \\
\hline Kidney+Inferior Vena Cava & 153 \\
Bladder & 65 \\
Ureters & 37 \\
Bowel segments & 24 \\
Pediatrics & 22 \\
Genitourinary reconstruction & 13 \\
Adrenal & 12 \\
Urethra & 8 \\
Other & 122 \\
\hline
\end{tabular}

Out of 647 presentations relating to robotic surgery, 108 (17\%) discussed new or improved techniques. Of those, 85 were video presentations, 18 were poster presentations, and only five were accepted for a podium presentation. Table 2 shows the stratification of the presentations dealing with innovative techniques. 
Table 2. Stratification of AUA 2016 and 2017 Surgical Innovation Presentations.

\begin{tabular}{|l|c|}
\hline Topic & $\begin{array}{c}\text { Surgical Innovation } \\
\text { Presentations }\end{array}$ \\
\hline Prostate & 41 \\
Kidney+Inferior Vena Cava & 29 \\
Bladder & 13 \\
Ureters & 8 \\
Bowel & 7 \\
Others & 4 \\
Adrenal & 3 \\
Pediatrics & 3 \\
\hline
\end{tabular}

\section{CONCLUSION}

Urology has been in the forefront of implementing and advancing robotic surgery in medicine. Since their development, robotic systems have been integrated into almost every aspect of urologic surgery. Even nearly 20 years after the appearance of the first robotic system, new technologies and indications are being published in increasing numbers annually. The last two AUA conferences included almost 650 publications involving robotassisted procedures.

There are numerous reports about medical device companies that are at advanced stages of developing new robotic systems for treating kidney stones and as an alternative to existing devices. We hope that competition will make robotic technology more affordable, and as robot systems become more prevalent they will assume a leading role in the future of surgery in general and in urology in particular.

\section{REFERENCES}

1. Shah J, Mackay S, Rockall T, Vale J, Darzi A. "Urobotics": Robots in urology. BJU Int 2001;88: 313-20. $\underline{\text { CrossRef }}$

2. Murphy D, Challacombe B, Khan MS, Dasgupta P. Robotic technology in urology. Postgrad Med J 2006; 82:743-7. CrossRef

3. Lanfranco AR, Castellanos AE, Desai JP, Meyers WC. Robotic surgery: a current perspective. Ann Surg 2004;239:14-21. $\underline{\text { CrossRef }}$

4. Guillonneau B. What robotics in urology? A current point of view. Eur Urol 2003;43: 103-5. CrossRef
5. Kumar R, Hemal AK. Emerging role of robotics in urology. J Minim Access Surg 2005;1:202-10.

6. Kavoussi LR, Moore RG, Adams JB, Partin AW. Comparison of robotic versus human laparoscopic camera control. J Urol 1995;154:2134-6. CrossRef

7. Hemal AK, Menon M. Laparoscopy, robot, telesurgery and urology: future perspective. J Postgrad Med 2002;48:39-41.

8. Marescaux J, Leroy J, Gagner M, et al. Transatlantic robot-assisted telesurgery. Nature 2001;413:379-80. CrossRef

9. Horgan S, Vanuno D. Robots in laparoscopic surgery. J Laparoendosc Adv Surg Tech A 2001;11:415-19. CrossRef

10. Brunaud L, Bresler L, Ayav A, et al. [Advantages of using robotic Da Vinci system for unilateral adrenalectomy: early results]. Ann Chir 2003;128:530-5. [Article in French] CrossRef

11. Benincà G, Garrone $\mathrm{C}$, Rebecchi F, Giaccone C, Morino M. [Robot-assisted laparoscopic surgery. Preliminary results at our center]. Chir Ital 2003; 55:321-31. [Article in Italian]

12. Ratner LE, Ciseck LJ, Moore RG, Cigarroa FG, Kaufman HS, Kavoussi LR. Laparoscopic live donor nephrectomy. Transplantation 1995;60:1047-9.

13. Klingler DW, Hemstreet GP, Balaji KC. Feasibility of robotic radical nephrectomy--initial results of singleinstitution pilot study. Urology 2005;65:1086-9. CrossRef

14. Stifelman MD, Caruso RP, Nieder AM, Taneja SS. Robot-assisted laparoscopic partial nephrectomy. JSLS 2005;9:83-6.

15. Cheung H, Wang Y, Chang SL, Khandwala Y, Del Giudice F, Chung BI. Adoption of robot-assisted partial nephrectomies: a population-based analysis of U.S. surgeons from 2004 to 2013. J Endourol 2017; 31:886-92. CrossRef

16. Abaza R. Initial series of robotic radical nephrectomy with vena caval tumor thrombectomy. Eur Urol 2011; 59:652-6. CrossRef

17. Clayman RV, Kavoussi LR, Figenshau RS, Chandhoke PS, Albala DM. Laparoscopic nephroureterectomy: initial clinical case report. J Laparoendosc Surg 1991; 1:343-9. CrossRef

18. Berger A, Haber GP, Kamoi K, et al. Laparoscopic radical nephroureterectomy for upper tract transitional cell carcinoma: oncological outcomes at 7 years. J Urol 2008;180:849-54; discussion 854. CrossRef

19. Rose K, Khan S, Godbole H, et al. Robotic assisted retroperitoneoscopic nephroureterectomy - first 
experience and the hybrid port technique. Int $\mathrm{J}$ Clin Pract 2006;60:12-14. $\underline{\text { CrossRef }}$

20. Horgan S, Vanuno D, Sileri P, Cicalese L, Benedetti E. Robotic-assisted laparoscopic donor nephrectomy for kidney transplantation. Transplantation 2002;73: 1474-9. CrossRef

21. Giulianotti P, Gorodner V, Sbrana F, et al. Robotic transabdominal kidney transplantation in a morbidly obese patient. Am J Transplant 2010;10:1478-82. CrossRef

22. Lynch RJ, Ranney DN, Shijie C, Lee DS, Samala N, Englesbe MJ. Obesity, surgical site infection, and outcome following renal transplantation. Ann Surg 2009;250:1014-20. CrossRef

23. Tegavarupu SP, Dasgupta P. Laparoscopic reconstructive urology. BJU Int 2005;95:724-6. $\underline{\text { CrossRef }}$

24. Hollis MV, Cho PS, Yu RN. Pediatric robot-assisted laparoscopic pyeloplasty. Am J Robot Surg 2015; 2:18. CrossRef

25. Boysen WR, Gundeti MS. Robot-assisted laparoscopic pyeloplasty in the pediatric population: a review of technique, outcomes, complications, and special considerations in infants. Pediatr Surg Int 2017;33: 92535. Erratum in: Pediatr Surg Int 2017;33:937. CrossRef

26. Minnillo BJ, Cruz JAS, Sayao RH, et al. Long-term experience and outcomes of robotic assisted laparoscopic pyeloplasty in children and young adults. $\mathrm{J}$ Urol 2011;185:1455-60. $\underline{\text { CrossRef }}$

27. Kozinn SI, Canes D, Sorcini A, Moinzadeh A. Robotic versus open distal ureteral reconstruction and reimplantation for benign stricture disease. J Endourol 2012;26:147-51. CrossRef

28. Glinianski M, Guru KA, Zimmerman G, Mohler J, Kim HL. Robot-assisted ureterectomy and ureteral reconstruction for urothelial carcinoma. J Endourol 2009;23:97-100. $\underline{\text { CrossRef }}$

29. Lee DI, Schwab CW, Harris A. Robot-assisted ureteroureterostomy in the adult: initial clinical series. Urology 2010;75:570-3. CrossRef

30. Musch M, Hohenhorst L, Pailliart A, Loewen H, Davoudi Y, Kroepfl D. Robot-assisted reconstructive surgery of the distal ureter: single institution experience in 16 patients. BJU Int 2013;111:773-83.

31. Beecken WD, Wolfram M, Engl T, et al. Roboticassisted laparoscopic radical cystectomy and intraabdominal formation of an orthotopic ileal neobladder. Eur Urol 2003;44:337-9. CrossRef

32. Bochner BH, Dalbagni G, Sjoberg DD, et al. Comparing open radical cystectomy and robot-assisted laparoscopic radical cystectomy: a randomized clinical trial. Eur Urol 2015;67:1042-50. $\underline{\text { CrossRef }}$
33. Nix J, Smith A, Kurpad R, Nielsen ME, Wallen EM, Pruthi RS. Prospective randomized controlled trial of robotic versus open radical cystectomy for bladder cancer: perioperative and pathologic results. Eur Urol 2010;57:196-201. $\underline{\text { CrossRef }}$

34. Parekh DJ, Messer J, Fitzgerald J, Ercole B, Svatek R. Perioperative outcomes and oncologic efficacy from a pilot prospective randomized clinical trial of open versus robotic assisted radical cystectomy. J Urol 2013;189:474-9. CrossRef

35. Xia L, Wang $\mathrm{X}, \mathrm{Xu} \mathrm{T}$, et al. Robotic versus open radical cystectomy: an updated systematic review and meta-analysis. PLoS One 2015;10:e0121032.

36. Davis RB, Farber NJ, Tabakin AL, Kim IY, Elsamra SE. Open versus robotic cystectomy: comparison of outcomes. Investig Clin Urol 2016;57(Suppl 1):S3643 .

37. Leow JJ, Reese SW, Jiang W, et al. Propensitymatched comparison of morbidity and costs of open and robot-assisted radical cystectomies: a contemporary population-based analysis in the United States. Eur Urol 2014;66:569-76. CrossRef

38. Lau CS, Blackwell RH, Quek ML. Radical cystectomy: open vs robotic approach. J Urol 2015;193:400-2. CrossRef

39. Smith ND, Castle EP, Gonzalgo ML, et al. The RAZOR (randomized open vs robotic cystectomy) trial: study design and trial update. BJU Int 2015;115:198-205. CrossRef

40. Amiel G, Shabtayev V, Aro T, el al. Robotic radical cystectomy - first series in Israel. 35th Annual Meeting of the Israeli Urological Association, November, 2015, Eilat, Israel. p. 26 [Hebrew]

41. Aro T, Kakiashvili D, Malshy K, Shabataev V, Amiel G. PD67-12 Safety \& feasibility of bladder and prostate robotic surgery after radiation therapy. J Urol 2017;197(Suppl):e1281. CrossRef

42. Allaparthi S, Ramanathan R, Balaji KC. Robotic partial cystectomy for bladder cancer: a singleinstitutional pilot study. J Endourol 2010;24:223-7. CrossRef

43. Elliott SP, Meng MV, Anwar HP, Stoller ML. Complete laparoscopic ileal cystoplasty. Urology 2002; 59:939-43. $\underline{\text { CrossRef }}$

44. Hsu TH, Shortliffe LD. Laparoscopic Mitrofanoff appendicovesicostomy. Urology 2004;64:802-4. CrossRef

45. Al-Othman KE, Al-Hellow HA, Al-Zahrani HM, Seyam RM. Robotic augmentation enterocystoplasty. J Endourol 2008;22597-600. CrossRef

46. Bricker EM. Bladder substitution after pelvic evisceration. Surg Clin North Am 1950;30:1511-21. CrossRef 
47. Wallace DM. Ureteric diversion using a conduit: a simplified technique. Br J Urol 1966;38:522-7. CrossRef

48. Colombo R, Naspro R. Ileal conduit as the standard for urinary diversion after radical cystectomy for bladder cancer. Eur Urol Suppl 2010;9:736-44. $\underline{\text { CrossRef }}$

49. Mariano MB, Graziottin TM, Tefilli MV. Laparoscopic prostatectomy with vascular control for benign prostatic hyperplasia. J Urol 2002;167: 2528-9. CrossRef

50. Mariano MB, Tefilli MV, Graziottin TM, Morales CM, Goldraich IH. Laparoscopic prostatectomy for benign prostatic hyperplasia - a six-year experience. Eur Urol 2006;49:127-31. $\underline{\text { CrossRef }}$

51. Sotelo R, Clavijo R, Carmona O, et al. Robotic simple prostatectomy. J Urol 2008;179:513-15. CrossRef

52. Schuessler WW, Schulam PG, Clayman RV, Kavoussi LR. Laparoscopic radical prostatectomy: initial shortterm experience. Urology 1997;50:854-7. $\underline{\text { CrossRef }}$

53. Pasticier G, Rietbergen JB, Guillonneau B, Fromont G, Menon M, Vallancien G. Robotically assisted laparoscopic radical prostatectomy: feasibility study in men. Eur Urol 2001;40:70-4. CrossRef

54. Yaxley JW, Coughlin GD, Chambers SK, et al. Robotassisted laparoscopic prostatectomy versus open radical retropubic prostatectomy: early outcomes from a randomised controlled phase 3 study. Lancet 2016; 388:1057-66. CrossRef

55. White WM, Kim ED. Interposition nerve grafting during radical prostatectomy: cumulative review and critical appraisal of literature. Urology 2009;74: 24550. $\underline{\text { CrossRef }}$

56. Davis JW, Chang DW, Chevray P, et al. Randomized phase II trial evaluation of erectile function after attempted unilateral cavernous nerve-sparing retropubic radical prostatectomy with versus without unilateral sural nerve grafting for clinically localized prostate cancer. Eur Urol 2009;55:1135-43. CrossRef

57. Kaouk JH, Desai MM, Abreu SC, Papay F, Gill IS. Robotic assisted laparoscopic sural nerve grafting during radical prostatectomy: initial experience. J Urol 2003;170:909-12. $\underline{\text { CrossRef }}$

58. Rassweiler JJ, Scheitlin W, Heidenreich A, Laguna MP, Janetschek G. Laparoscopic retroperitoneal lymph node dissection: does it still have a role in the management of clinical stage I nonseminomatous testis cancer? A European perspective. Eur Urol 2008;54:1004-15. CrossRef

59. Williams SB, Lau CS, Josephson DY. Initial series of robot-assisted laparoscopic retroperitoneal lymph node dissection for clinical stage I nonseminomatous germ cell testicular cancer. Eur Urol 2011;60:1299302. CrossRef

6o. Cheney SM, Andrews PE, Leibovich BC, Castle EP. Robot-assisted retroperitoneal lymph node dissection: technique and initial case series of 18 patients. BJU Int 2015;115:114-20. CrossRef

61. Fleming C. Robot-assisted vasovasostomy. Urol Clin North Am 2004;31:769-72. $\underline{\text { CrossRef }}$

62. Gudeloglu A, Brahmbhatt JV, Parekattil SJ. Robotassisted microsurgery in male infertility and andrology. Urol Clin North Am 2014;41:559-66. CrossRef

63. Parekattil SJ, Gudeloglu A, Brahmbhatt J, Wharton J, Priola KB. Robotic assisted versus pure microsurgical vasectomy reversal: technique and prospective database control trial. J Reconstr Microsurg 2012;28: 435-44. CrossRef

64. Trost L, Parekattil S, Wang J, Hellstrom WJ. Intracorporeal robot-assisted microsurgical vasovasostomy for the treatment of bilateral vasal obstruction occurring following bilateral inguinal hernia repairs with mesh placement. J Urol 2014;191:1120-5. CrossRef

65. Shu T, Taghechian S, Wang R. Initial experience with robot-assisted varicocelectomy. Asian J Androl 2008;10:146-8. CrossRef

66. Mechlin C, McCullough A. V1590 robotic microsurgical varicocele repair: initial experience and surgical outcomes from a single academic center. $\mathrm{J}$ Urol 2013;189:e652-3. $\underline{\text { CrossRef }}$

67. Schlegel PN. Nonobstructive azoospermia: a revolutionary surgical approach and results. Semin Reprod Med 2009;27:165-70. $\underline{\text { CrossRef }}$

68. Gudeloglu A, Brahmbhatt JV, Parekattil SJ. Robotic microsurgery in male infertility and urology — taking robotics to the next level. Transl Androl Urol 2014;3:102-12. 